\title{
PROMOSI KESEHATAN BERBASIS DARING MENGENAI PERILAKU PENCEGAHAN COVID-19 BAGI MASYARAKAT KOTA KENDARI
}

Suhadi ${ }^{1}$, Nurmaladewi ${ }^{2}$, Yasnani ${ }^{3}$, Lymbran Tina ${ }^{4}$

${ }^{1234}$ Fakultas Kesehatan Masyarakat, Universitas Halu Oleo

Email: suhaditsel77@yahoo.com

\section{RINGKASAN}

Pandemi COVID-19 yang dideklarasikan oleh World Health Organization (WHO) sejak akhir Januari tahun 2020 merupakan masalah kesehatan masyarakat yang sedang dihadapi oleh seluruh dunia termasuk masyarakat Kota Kendari. Jumlah kasus COVID-19 di Kota Kendari sebanyak 17 kasus terkonfirmasi positif, 4 pasien dinyatakan sembuh, dan 2 pasien meninggal (data diakses 23 April 2020). Salah satu tempat umum yang berisiko untuk menjadi tempat penularan COVID-19 ialah swalayan dimana banyak masyarakat datang untuk berbelanja kebutuhan seharihari namun penerapan protokol kesehatan di swalayan masih belum maksimal sehingga berpotensi menjadi tempat penularan COVID-19. Tujuan pengabdian ini ialah untuk meningkatkan pengetahuan, kesadaran, dan perilaku masyarakat dalam menerapkan protokol kesehatan pencegahan COVID-19 guna memutus rantai penularan COVID-19. Metode yang digunakan dalam pengabdian ialah promosi kesehatan melalui daring dan luring, promosi kesehatan secara daring dilakukan dengan pembuatan video penyuluhan kesehatan yang kemudian disebar di berbagai sosial media dan metode promosi kesehatan secara luring dilakukan dengan penyebaran pamflet, poster disertai dengan pembagian masker, hand sanitizer, dan sabun cuci tangan di beberapa swalayan di Kota Kendari. Hasil pengabdian ini adalah pengunjung swalayan-swalayan khususnya dan masyarakat di Kota Kendari umumnya memiliki pengetahuan dan peningkatan kesadaran dalam menerapkan perilaku-perilaku pencegahan COVID-19.

\section{Kata kunci: Promosi; Perilaku; Pencegahan; COVID-19}

\section{A. Latar Belakang}

Pandemi merupakan masalah kesehatan masyarakat global yang dapat mempengaruhi kondisi di berbagai negara yang terinfeksi. Pandemi COVID-19 yang dideklarasikan oleh World Health Organization (WHO) sejak akhir Januari tahun 2020 merupakan masalah kesehatan masyarakat yang sedang dihadapi oleh seluruh dunia saat ini (WHO 2020). Penyakit Coronavirus atau Coronavirus Disease 2019 (COVID-19) disebabkan oleh Severe Acute Respiratory Syndrome Coronavirus 2 (SARS-CoV-2) (Kemenkes RI 2020c). Penyakit COVID-19 merupakan penyakit baru yang mengakibatkan 
infeksi pada saluran pernapasan manusia serta memiliki tingkat penularan cukup tinggi (Lai et al. 2020; Machhi et al. 2020).

Kasus COVID-19 awalnya ditemukan di Kota Wuhan, China yang kemudian menyebar ke berbagai negara lainnya. Data WHO terbaru per tanggal 23 April 2020 menunjukkan bahwa jumlah kasus positif sebanyak 2.549.632 kasus dengan kasus kematian sebanyak 175.825. Jumlah kasus ini tersebar di 213 negara di berbagai belahan dunia (WHO 2020). Kasus COVID-19 dikonfirmasi di Indonesia pada tanggal 2 Maret 2020. Saat ini kasus positif COVID-19 di Indonesia sebanyak 7.775 orang, 6.168 pasien dalam perawatan, 960 pasien dinyatakan sembuh dan 647 pasien meninggal yang tersebar di berbagai provinsi di Indonesia (Gugus Tugas COVID-19 RI 2020).

Provinsi Sulawesi Tenggara saat ini juga merupakan wilayah yang sudah ditetapkan oleh Kementerian Kesehatan sebagai daerah transmisi lokal COVID-19 yang berarti penularan yang terjadi antarorang ke orang dalam suatu wilayah. Kota Kendari sebagai ibu kota Provinsi Sulawesi Tenggara saat ini memiliki jumlah kasus COVID-19 terbanyak dibanding kabupaten lainnya. Jumlah kasus COVID-19 di Kota Kendari sebanyak 17 kasus, 4 pasien sembuh, dan 2 pasien meninggal (Gugus Tugas Covid-19 Sultra 2020; Kemenkes RI 2020a). Jumlah kasus yang meningkat dapat disebabkan oleh beberapa hal, yakni: kurangnya pengetahuan masyarakat mengenai proses penularan COVID-19 sehingga masih banyak masyarakat yang keluar rumah tanpa kepentingan mendesak serta kurangnya kesadaran masyarakat dalam menerapkan perilaku-perilaku pencegahan COVID-19 seperti penggunaan masker, penggunaan cairan pembersih atau hand sanitizer, mencuci tangan pakai sabun, menjaga jaga jarak dengan orang lain (physical distancing), protokol ketika masuk ke dalam rumah setelah bepergian ke luar rumah, protokol menerima barang dari jasa kurir, protokol saat berbelanja kebutuhan pangan atau lainnya serta asupan makanan yang sehat dalam menjaga imunitas tubuh.

Salah satu tempat umum yang berisiko untuk menjadi tempat penularan COVID19 ialah swalayan dimana banyak masyarakat datang untuk berbelanja kebutuhan seharihari namun penerapan protokol kesehatan di swalayan masih belum maksimal sehingga berpotensi menjadi tempat penularan COVID-19. Olehnya tim pengabdian merasa perlu 
turut andil dalam upaya pengendalian COVID-19 khususnya di Kota Kendari dengan melakukan pengabdian dengan tema "Promosi Kesehatan Berbasis Daring Mengenai Perilaku Pencegahan Covid-19 Bagi Masyarakat Kota Kendari". Tim pengabdian melakukan promosi kesehatan kepada masyarakat secara umum dalam upaya meningkatkan pengetahuan masyarakat mengenai perilaku pencegahan COVID-19 agar masyarakat dapat mengetahui dan dapat menerapkan perilaku-perilaku yang dapat mencegah serta memutus rantai penularan COVID-19 melalui pembuatan membuat video, pamflet serta poster berbasis daring berisi pesan-pesan terkait perilaku pencegahan COVID-19 dan juga menyebarkan poster dan pamflet langsung serta pembagian masker, hand sanitizer, dan sabun cuci tangan di berbagai swalayan-swalayan besar di Kota Kendari (Swalayan Indogrosir Anduonohu, Hypermart Lippo Kendari, Swalayan MGM Baruga, Swalayan Sanya Kadia, Swalayan Surya Mandonga dan Swalayan Nusantara Kendari Barat).

\section{B. Metode Pelaksanaan}

Pengabdian kepada masyarakat dilaksanakan selama satu bulan mulai tanggal 11 Juni 2020 sampai dengan 11 Juli 2020 bertempat di Kota Kendari. Metode pelaksanaan pengabdian meliputi tiga tahap yakni:

\section{Tahap Persiapan}

Tahap persiapan meliputi survei awal serta penelusuran perkembangan data COVID-19 di Kota Kendari dengan tujuan untuk mengetahui fenomena masyarakat terkait COVID-19 serta penerapan protokol kesehatan di masa pandemi dan memasuki new normal life yang kemudian menjadi input dalam penyusunan program-program promosi kesehatan yang dapat dilakukan.

\section{Tahap Pelaksanaan}

Tahap pelaksanaan program-program pengabdian meliputi pembuatan akun di berbagai media sosial (youtube, facebook, whatsapp group, dan instagram), pembelian masker, hand sanitizer, dan sabun cuci tangan, pembuatan video mengenai gambaran tentang COVID-19 dan perilaku pencegahan yang dapat dilakukan oleh masyarakat, pembuatan poster dan pamflet terkait perilaku pencegahan COVID-19 
(gambaran COVID-19 dan risiko penularannya, perkembangan kasus COVID-19 di Kota Kendari, pentingnya "tetap di rumah saja", cara menggunakan dan melepas masker yang benar, cara mencuci tangan pakai sabun yang benar, cara membersihkan tangan dengan hand sanitizer, cara membersihkan rumah dengan desinfektan, jaga jarak dengan orang lain (physical distancing), tindakan pencegahan yang harus dilakukan ketika hendak masuk ke dalam rumah setelah bepergian ke luar rumah, tindakan pencegahan yang dilakukan ketika menerima barang dari jasa kurir atau dari orang lain di luar rumah, tindakan pencegahan yang dilakukan saat berbelanja kebutuhan pangan atau lainnya di swalayan/pasar/lainnya, dan asupan makanan yang sehat sebagai upaya menjaga imunitas tubuh), penyebarluasan video dan poster mengenai COVID-19 dan pencegahannya melalui berbagai media sosial (youtube, facebook, whatsapp group, dan instagram), penyebaran pamflet dan poster mengenai perilaku pencegahan COVID-19 bersamaan dengan pembagian masker, hand sanitizer, dan sabun cuci tangan yang dilakukan di swalayan-swalayan Kota Kendari (Swalayan Indogrosir Anduonohu, Hypermart Lippo Kendari, Swalayan MGM Baruga, Swalayan Sanya Kadia, Swalayan Surya Mandonga dan Swalayan Nusantara Kendari Barat).

\section{Tahap Evaluasi}

Tahap evaluasi terhadap program-program pengabdian kepada masyarakat ialah dengan terus melakukan promosi kesehatan secara daring melalui berbagai sosial media bagi masyarakat Kota Kendari.

\section{Hasil dan Pembahasan}

\section{Intervensi Secara Daring}

a. Pembuatan dan penyebarluasan video promosi kesehatan secara daring

Video penyuluhan kesehatan membahas mengenai gambaran COVID-19 meliputi apa itu virus corona, bagaimana gejalanya, metode untuk mencegah virus corona, langkah-langkah aman dalam menghadapi kebijakan new normal/adaptasi kebiasaan baru dan metode pencegahan virus corona atau persiapan yang dilakukan pada saat di tempat kerja. Masyarakat diberikan pemahaman secara detail sehingga masyarakat memiliki pemahaman yang baik dan tetap disiplin tidak lalai terhadap 
protokol kesehatan dalam mencegah penularan COVID-19. Video penyuluhan kemudia diunggah dan disebar secara daring melalui berbagai akun sosial media yakni Youtube, Whatsapp, Instagram, dan Facebook dengan harapan banyak masyarakat yang akan mengakses video penyuluhan sehingga pesan kesehatan dapat tersampaikan kepada masyarakat dalam rangka mengenali COVID-19 dan langkah-langkah pencegahan yang harus dilakukan guna memutus rantai penularan COVID-19 di Kota Kendari khususnya.

b. Pembuatan dan penyebarluasan poster secara daring

Kegiatan pembuatan poster berbasis daring dilaksanakan selama 1 minggu kemudian diunggah dan disebarluaskan di berbagai media sosial yakni Youtube, Whatsapp, Instagram, dan Facebook. Terdapat sebelas poster berbasis daring yang sesuai panduan protocol kesehatan dari Kementerian Kesehatan RI dan WHO meliputi pentingnya "tetap di rumah saja", cara menggunakan dan melepas masker yang benar, cara mencuci tangan pakai sabun yang benar, cara membersihkan tangan dengan hand sanitizer, cara membersihkan rumah dengan desinfektan, jaga jarak dengan orang lain (physical distancing), tindakan pencegahan yang harus dilakukan ketika hendak masuk ke dalam rumah setelah bepergian ke luar rumah, tindakan pencegahan yang dilakukan ketika menerima barang dari jasa kurir atau dari orang lain di luar rumah, tindakan pencegahan yang dilakukan saat berbelanja kebutuhan pangan atau lainnya di swalayan/pasar/lainnya, dan asupan makanan yang sehat sebagai upaya menjaga imunitas tubuh.

\section{Intervensi Secara Luring}

a. Pembuatan dan penempelan poster mengenai mengenai COVID-19 dan upaya pencegahan COVID-19 di beberapa swalayan Kota Kendari

Poster-poster perilaku pencegahan COVID-19 yang telah dibuat selain disebarkan melalui berbagai media sosial, juga ditempel di enam (6) swalayan besar di Kota Kendari yakni Swalayan Indogrosir Anduonohu, Hypermart Lippo Kendari, Swalayan MGM Baruga, Swalayan Sanya Kadia, Swalayan Surya 
Mandonga dan Swalayan Nusantara Kendari Barat agar masyarakat dapat membaca dan memahami pesan-pesan kesehatan yang disampaikan melalui poster-poster tersebut dan dapat menerapkan dalam kehidupan sehari-hari dalam upaya pencegahan COVID-19.

Poster yang dibuat meliputi perkembangan kasus COVID-19 di Kota Kendari, pentingnya "tetap di rumah saja", cara menggunakan dan melepas masker yang benar, cara mencuci tangan pakai sabun yang benar, cara membersihkan tangan dengan hand sanitizer, cara membersihkan rumah dengan desinfektan, jaga jarak dengan orang lain (physical distancing), tindakan pencegahan yang harus dilakukan ketika hendak masuk ke dalam rumah setelah bepergian ke luar rumah, tindakan pencegahan yang dilakukan ketika menerima barang dari jasa kurir atau dari orang lain di luar rumah, tindakan pencegahan yang dilakukan saat berbelanja kebutuhan pangan atau lainnya di swalayan/pasar/lainnya, dan asupan makanan yang sehat sebagai upaya menjaga imunitas tubuh ke beberapa swalayan di Kota Kendari.

b. Pembuatan dan penempelan pamflet mengenai COVID-19 dan upaya pencegahan COVID-19 di beberapa swalayan Kota Kendari

Tim pengabdian membuat pamflet sebagai media promosi kesehatan selain video dan poster dengan harapan dapat membaca dan memahami pesan-pesan kesehatan yang disampaikan melalui poster-poster tersebut dan dapat menerapkan dalam kehidupan sehari-hari dalam upaya pencegahan COVID-19. Pamflet disebar di enam (6) swalayan besar di Kota Kendari yakni Swalayan Indogrosir Anduonohu, Hypermart Lippo Kendari, Swalayan MGM Baruga, Swalayan Sanya Kadia, Swalayan Surya Mandonga dan Swalayan Nusantara Kendari Barat. Pamflet yang dibuat ada sebelas macam yakni perkembangan kasus COVID-19 di Kota Kendari, pentingnya "tetap di rumah saja", cara menggunakan dan melepas masker yang benar, cara mencuci tangan pakai sabun yang benar, cara membersihkan tangan dengan hand sanitizer, cara membersihkan rumah dengan desinfektan, jaga jarak dengan orang lain (physical 
distancing), tindakan pencegahan yang harus dilakukan ketika hendak masuk ke dalam rumah setelah bepergian ke luar rumah, tindakan pencegahan yang dilakukan ketika menerima barang dari jasa kurir atau dari orang lain di luar rumah, tindakan pencegahan yang dilakukan saat berbelanja kebutuhan pangan atau lainnya di swalayan/pasar/lainnya, dan asupan makanan yang sehat sebagai upaya menjaga imunitas tubuh.

c. Pembagian masker kepada pengunjung di beberapa swalayan di Kota Kendari

Salah satu protokol kesehatan dalam upaya pencegahan COVID-19 ialah penggunaan masker yang dapat melindungi manusia dari infeksi virus corona yang diketahui menyebar melalui droplet. Fenomena yang ditemui di lapangan masih banyak masyarakat yang tidak acuh dalam penggunaan masker. Masyarakat masih banyak yang belum bahwa apabila dirinya positif corona bisa saja menulari orang lain tanpa sengaja ketika berinteraksi tanpa masker.

Tim pengabdian turut membagikan masker kain kepada pengunjung swalayan utamanya pada pelanggan yang saat ditemui tidak menggunakan masker. Ratusan masker dibagikan di di enam (6) swalayan besar di Kota Kendari yakni Swalayan Indogrosir Anduonohu, Hypermart Lippo Kendari, Swalayan MGM Baruga, Swalayan Sanya Kadia, Swalayan Surya Mandonga dan Swalayan Nusantara Kendari Barat karena swalayan-swalayan tersebut paling banyak jumlah pengunjungnya. Selain pembagian anggota tim juga melakukan edukasi personal kepada pengunjung yang tidak menggunakan masker dengan alasan lupa ataupun malas karena merasa kurang nyaman dan ada juga yang mengaku merasa sesak napas selama menggunakan masker. Edukasi personal dilakukan guna mengingatkan kembali masyarakat bagaimana risiko penularan COVID-19 yang tinggi terlebih di tempat-tempat umum dalam hal ini swalayan yang ramai dikunjungi oleh masyarakat. Selain itu kami juga mengadvokasi kepada pihak manajemen swalayan untuk menerapkan aturan larangan masuk ke swalayan apabila pengunjung tidak menggunakan masker dan hal ini diterima dengan baik 
oleh pihak manajemen mengingat swalayan sebagai salah satu tempat umum yang berpotensi menjadi tempat penyebaran COVID-19.

d. Pembagian sabun cuci tangan kepada pengunjung di beberapa swalayan di Kota Kendari

Salah satu tahap kewaspadaan standar yang efektif dalam pencegahan dan pengendalian infeksi ialah hand hygiene (kebersihan tangan), begitupun dalam mencegah penularan virus corona COVID-19, mencuci tangan dengan sabun merupakan salah satu hal yang paling esensial. Tangan yang kotor sehabis memegang fasilitas publik kadang masuk ke mulut saat makan, mengucek mata, memegang hidung sehingga virus bisa masuk ke dalam tubuh.

Tim pengabdian membagikan sabun cuci tangan untuk digunakan di tempat cuci tangan pada bagian pintu depan swalayan pada enam (6) swalayan besar di Kota Kendari yakni Swalayan Indogrosir Anduonohu, Hypermart Lippo Kendari, Swalayan MGM Baruga, Swalayan Sanya Kadia, Swalayan Surya Mandonga dan Swalayan Nusantara Kendari Barat diharapkan pengunjung akan mencuci tangan sebelum masuk ke swalayan. Hal ini diharapkan agar masyarakat terbiasa untuk cuci tangan sebelum memegang banyak barang di dalam swalayan dan diharapkan menjadi kebiasaan bagi masyarakat apabila berada di tempat-tempat umum lebih sering mencuci tangan agar tangan selalu bersih sehingga dapat mencegah masuknya virus ke dalam tubuh. Kami juga mengadvokasi kepada pihak manajemen swalayan untuk menerapkan aturan larangan masuk ke swalayan apabila pengunjung tidak mencuci tangan dan hal ini diterima dengan baik oleh pihak manajemen dengan menempatkan salah satu karyawan untuk mengarahkan pengunjung yang akan masuk untuk mencuci tangan. Selain sabun cuci tangan kami juga menempelkan poster cara mencuci tangan dengan baik dan benar sesuai anjuran dari Kementerian Kesehatan RI. 
e. Pembagian hand sanitizer kepada pengunjung di beberapa swalayan di Kota Kendari

Tangan adalah bagian tubuh yang sangat rentan menjadi tempat bersarangnya virus dan bakteri. Saat melakukan berbagai aktivitas, secara sadar maupun tidak sadar tangan sering kali berinteraksi dengan hal-hal yang dapat menebarkan kontaminasi misalnya membuka pintu, memegang tangga dan berjabat tangan. Dampak yang ditimbulkan akibat kebiasaan tidak menjaga kebersihan tangan berupa dampak ringan hingga berat. Diantaranya yaitu tubuh akan lebih rentan terserang virus yang sekarang yang lagi mewabah yaitu COVID19.

Tim pengabdian membagikan hand sanitizer untuk digunakan oleh pengunjung swalayan di enam (6) swalayan besar di Kota Kendari yakni Swalayan Indogrosir Anduonohu, Hypermart Lippo Kendari, Swalayan MGM Baruga, Swalayan Sanya Kadia, Swalayan Surya Mandonga dan Swalayan Nusantara Kendari Barat. Hal ini untuk menjaga kebersihan tangan para pengunjung dimana sebagai jalur tempat masuknya virus corona. Selain itu kami mengadvokasi juga kepada pihak manajemen untuk menyediakan tempat cuci tangan di bagian depan pintu masuk swalayan agar para pengunjung bisa mencuci tangan sebelum masuk atau memberikan hand sanitizer kepada pengunjung guna menjaga kebersihan tangan pengunjung dan tentunya mencegah penyebaran COVID-19 di swalayan.

Hasil dari pengabdian yang dilakukan ialah dapat memberikan tambahan pengetahuan dan kesadaran bagi masyarakat dalam menerapkan protokol kesehatan sebagai upaya mencegah COVID-19. Selain itu juga sebagai jalur advokasi kepada manajemen swalayan untuk dapat menerapkan aturan protokol kesehatan di swalayan mengingat swalayan sebagai salah satu tempat umum yang sering dikunjungi. 


\section{Kesimpulan}

1. Promosi kesehatan secara daring telah dilakukan dengan pembuatan video penyuluhan kesehatan yang telah dinonton oleh banyak orang dan poster mengenai pencegahan penularan penyakit COVID-19 dan bagaimana penerapan protokol kesehatan dalam kehidupan sehari-hari utamanya dalam "new normal life" kemudian disebarkan kepada masyarakat melalui berbagai media sosial (youtube, facebook, whatsapp group, dan instagram),

2. Promosi kesehatan secara luring telah dilakukan dengan pembuatan dan penyebaran
ratusan media-media promosi kesehatan cetak (poster dan pamflet) berisi pesan-
pesan kesehatan sebanyak sebelas (11) macam di enam (6) swalayan besar di Kota
Kendari berisi perkembangan kasus COVID-19 di Kota Kendari,

Promosi kesehatan secara luring telah dilakukan dengan pembuatan dan penyebaran
ratusan media-media promosi kesehatan cetak (poster dan pamflet) berisi pesan-
pesan kesehatan sebanyak sebelas (11) macam di enam (6) swalayan besar di Kota
Kendari berisi perkembangan kasus COVID-19 di Kota Kendari,

Promosi kesehatan secara luring telah dilakukan dengan pembuatan dan penyebaran
ratusan media-media promosi kesehatan cetak (poster dan pamflet) berisi pesan-
pesan kesehatan sebanyak sebelas (11) macam di enam (6) swalayan besar di Kota
Kendari berisi perkembangan kasus COVID-19 di Kota Kendari, Kendari berisi perkembangan kasus COVID-19 di Kota Kendari,

3. Promosi kesehatan secara luring juga telah dilakukan dengan membagikan masker kain, hand sanitizer, dan sabun cuci tangan kepada pengunjung di enam (6) swalayan besar di Kota Kendari

\section{E. UCAPAN TERIMAKASIH}

Tim pengabdian mengucapkan terimakasih kepada Lembaga Penelitian dan Pengabdian Masyarakat (LPPM) Universitas Halu Oleo (UHO) atas bantuannya dalam pendanaan kegiatan pengabdian masyarakat sehingga dapat terlaksana dengan baik. Selain itu Kami juga berterimakasih kepada pihak pemerintah, pihak manajemen swalayan-swalayan dan masyarakat Kota Kendari yang telah bekerjasama dengan baik dalam kegiatan pengabdian kepada masyarakat ini.

\section{DAFTAR PUSTAKA}

Gugus Tugas COVID-19 RI. 2020. "Situasi COVID-19 Di Indonesia." : https://www.covid19.go.id/situasi-virus-corona/. https://www.covid19.go.id/situasivirus-corona/ (April 23, 2020).

Gugus Tugas Covid-19 Sultra. 2020. "Situasi COVID-19 Di Sulawesi Tenggara." https://www.facebook.com/satgascovid19sultra/photos/pcb.129631792015280/129 63176868194 (July 28, 2020).

Kemenkes RI. 2020a. "Dashboard Data Kasus COVID-19 Di Indonesia." https://www.kemkes.go.id/article/view/20031900002/Dashboard-Data-KasusCOVID-19-di-Indonesia.htm/. https://www.kemkes.go.id/article/view/20031900002/Dashboard-Data-Kasus- 
COVID-19-di-Indonesia.html.

- 2020b. 1 Pedoman Pencegahan dan Pengendalian Coronavirus Disease (COVID-

19) Pedoman Pencegahan Dan Pengendalian Coronavirus Disease (COVID-19). 4th

ed. Jakarta: Kementerian Kesehatan Republik Indonesia.

—. 2020c. "Situasi COVID-19 Di Indonesia." Kementerian Kesehatan Republik Indonesia. https://www.kemkes.go.id/article/view/20012900002/Kesiapsiagaanmenghadapi-Infeksi-Novel-Coronavirus.html (July 28, 2020).

Lai, Chih Cheng et al. 2020. "Severe Acute Respiratory Syndrome Coronavirus 2 (SARSCoV-2) and Coronavirus Disease-2019 (COVID-19): The Epidemic and the Challenges." International Journal of Antimicrobial Agents 55(3). https://pubmed.ncbi.nlm.nih.gov/32081636/ (July 29, 2020).

Machhi, Jatin et al. 2020. "The Natural History, Pathobiology, and Clinical Manifestations of SARS-CoV-2 Infections." Journal of Neuroimmune Pharmacology: 1. http://link.springer.com/10.1007/s11481-020-09944-5 (July 29, 2020).

WHO. 2020. Coronavirus Disease (COVID-19) Situation Report - 189. https://www.youtube.com/watch?v=yjdiGRRAxjg (July 28, 2020). 